\title{
Globalization and populism in Europe
}

\author{
Andreas Bergh ${ }^{1,2} \cdot$ Anders Kärnä2,3
}

Received: 18 February 2020 / Accepted: 22 October 2020 / Published online: 19 November 2020

(c) The Author(s) 2020

\begin{abstract}
Recent micro-level studies have suggested that globalization-in particular, economic globalization and trade with China-breeds political polarization and populism. This study examines whether or not those results generalize by examining the country-level association between vote shares for European populist parties and economic globalization. Using data on vote shares for 267 right-wing and left-wing populist parties in 33 European countries during 1980-2017, and globalization data from the KOF institute, we find no evidence of a positive association between (economic or other types of) globalization and populism. EU membership is associated with a 4-6-percentage-point larger vote share for right-wing populist parties.
\end{abstract}

Keywords Globalization · Populism · Trade

JEL Classification P16 · F68

\section{Introduction}

I concur with the commonplace judgment that the rise of populism has been triggered by globalization and the consequent massive increase in inequality in many rich countries-Francis Fukuyama (2019).

Populist parties are on the rise in western democracies. Several studies provide some support for the view (expressed by Fukuyama quoted above) that economic globalization is one of the most important causes-but the evidence is not conclusive. For

Electronic supplementary material The online version of this article (https://doi.org/10.1007/s1112 7-020-00857-8) contains supplementary material, which is available to authorized users.

Andreas Bergh

andreas.bergh@ifn.se

Anders Kärnä

anders.karna@oru.se

1 Lund University, Lund, Sweden

2 The Research Institute of Industrial Economics (IFN), Box 55665, 10215 Stockholm, Sweden

3 Örebro University, Örebro, Sweden 
example, Swank and Betz (2003) studied 16 European countries from 1981 to 1998, and documented a positive association between economic openness and votes for right-wing populist parties where social spending is low, but a negative association where social spending is high. More recently, Autor et al. (2020) showed show that congressional districts exposed to larger increases in import penetration disproportionately removed moderate representatives from office, replacing them with more extreme candidates. Dippel et al. (2015) showed that trade integration with China and Eastern Europe increases support for extreme-right parties in Germany, identifying changes in manufacturing employment as a mechanism. Similar results for 15 Western European countries were presented by Colantone and Stanig (2018b), who showed that Chinese import shocks have strengthened support for nationalist and isolationist parties. In a related paper, the same authors (Colantone and Stanig 2018a) also showed that support for the Leave option in the Brexit referendum was larger in regions "hit harder" by economic globalization.

It is not obvious, however, that results driven by Chinese import shocks can be generalized to a positive association between country level (economic) globalization and votes for populist parties. Commenting on Autor et al. (2020), Krugman (2016) noted that effects identified in the United States estimated for sectors with import-competing industries are unlikely to generalize even to the entire US economy. Chinese imports may well have raised wages and created employment elsewhere in the US economy, with potentially mitigating political consequences. In any case, globalization is a multidimensional process, and economic globalization entails more than trade with China.

When discussing the evidence that globalization breeds populism, another factor worth mentioning is publication bias (Stanley 2005; Auspurg and Hinz 2011), such that studies finding insignificant effects of globalization on any outcome are less likely to be published. If researchers anticipate publication bias, any field of scholarship is likely to suffer from production bias, in the sense that papers reporting statistically significant findings are more likely to be written, completed and submitted (what Rosenthal (1979) called the file drawer problem). Both mechanisms suggest that previously published findings may give a biased view of how globalization and populism are associated.

This paper relies on a newly released compilation of election results since 1980 for populist parties in 33 European countries (Heinö 2016) and the newly updated KOF index of globalization (Gygli et al. 2019) to examine the association between different types of globalization and votes for populist parties over the 1980-2017 period. If the commonplace judgment alluded to by Fukuyama is correct, the causal effects identified in previous research should generalize to a positive cross-country association between economic globalization and votes for populist parties. As we shall see, however, that is not the case. The absence of a country-level association between globalization and populism is robust to a large array of variations in methodologies and in the measurement of both globalization and populism.

The paper proceeds by discussing in Sect. 2 the definition and measurement of populism, while Sect. 3 introduces the reader to some of the frequently mentioned theoretical reasons that globalization might reinforce populism. Section 4 describes the data and presents the empirical analysis, including several robustness tests (full regression output from those tests is available in an online appendix or from the authors). Section 5 concludes the paper. 


\section{Defining and measuring populism}

Many scholars have discussed the nature and definition of populism. ${ }^{1}$ Some early studies focused on the differences between parties and movements mobilizing under the populist label-Canovan (1981) is one example. After contributions by, among others, Mudde (2004), Mudde and Kaltwasser (2017) and Taggart (2000, 2004), the literature is approaching a consensus on what Huber and Schimpf (2017) call a minimal definition of populism, based on three elements: an appeal to the people, a denunciation of the elite, and the idea that politics should be an expression of the "general will". The ideas typically are attached to a host ideology, which for left-wing populists often is socialism in some form, and for right-wing populists some type of nationalism. ${ }^{2}$ Along those lines, Rodrik (2018) distinguishes between left-wing and right-wing populism because they differ with respect to the societal cleavages that populists highlight. The distinction between right-wing and leftwing populism is also important because empirical studies have shown that left-wing and right-wing populist parties behave differently in parliaments, and that the left-right positions of the parties can be more important than their shared populism (Otjes and Louwerse 2015; Huber and Schimpf 2017).

The present paper relies mainly on the classification by Heinö (2016), who identified both right-wing and left-wing populist parties in democratic European countries based on the scientific literature examining the European party system and the Chapel Hill Expert Survey. The compilation contains vote shares for 267 parties in 33 countries (the $28 \mathrm{EU}$ countries plus Iceland, Norway, Switzerland, Serbia and Montenegro) from 1980 to the present day, accounting for the fact that parties may change over time. For example, the Freedom Party of Austria (FPÖ) is included from 1986, when Jörg Haider was appointed and made anti-immigration politically salient. Hungary's Fidesz is classified as populist starting in 2002. Countries are included in the index when they are free according to the Freedom House index: Most Middle and Eastern European countries are included from 1990 onward. Hence, most post-communist countries are included from 1990, Serbia in 2000 and Croatia in 2001. Based on the most recent elections, the largest populist parties in Europe are "Fidesz - Magyar Polgäri Szövetség" (Hungarian Civic Alliance) and "Prawo i Sprawiedliwość" (Law and justice) in Poland (both right-wing populist) and "Synaspismos Rizospastikis Aristeras" (abbreviated Syriza, the coalition of Greece's radical left) (leftwing populist).

To avoid relying on one index only, we have verified our main results using Populist 2.0 (as updated in January 2020), a project initiated by the newspaper The Guardian. It consists of a list of European populist parties (based on several experts in each country) from 31 countries starting in 1989. Both indices distinguish between right-wing and left-wing populism, and our slight preference for Heinö (2016) is based on country-year coverage only. As can be seen from Fig. 1, the two sources largely agree on the aggregate trends for both types of populism in Europe.

\footnotetext{
${ }^{1}$ Recent contributions include Müller (2016) and Norris and Inglehart (2019).

${ }^{2}$ Left-wing and right-wing populism is sometimes referred to as inclusive and exclusive populism.
} 
Comparing Heinö (2016) and The PopuList 2.0

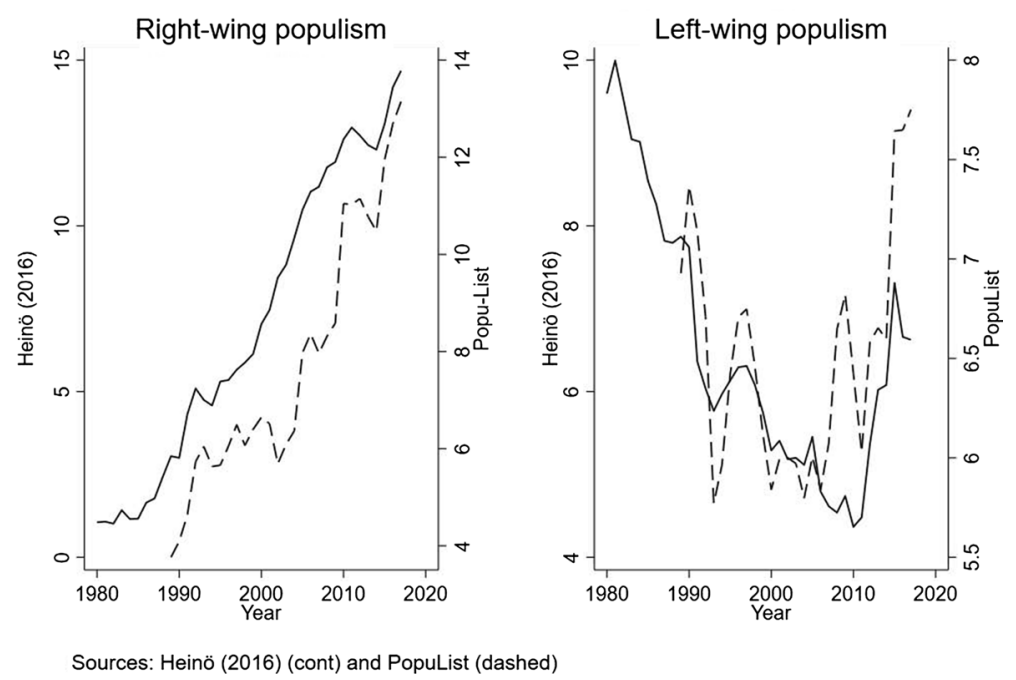

Fig. 1 Populism with different data sources. Right- and left-wing populism with different sources. The PopuList (popu-list.org) definition includes both far-right and far-right populist, as well as far-left and far-left populists, which we have merged into one category to make it comparable with Heinö (2016)

\section{Globalization and populism: theoretical considerations}

Why would globalization (economic or other types) breed populism? An accessible overview is provided by Margalit (2019), who discusses trade, deindustrialization, financial crises and immigration, and questions the relevance of all of those explanations.

Studies that emphasize the path from economic globalization to populism, including Colantone and Stanig (2018b) and Swank and Betz (2003), typically refer to the theories of embedded liberalism (Ruggie 1982) and the compensation hypothesis (Katzenstein 1985; Rodrik 1998). The basic idea is that economic globalization increases volatility by exposing national economies to shocks and also changes economic structures, creating losers in line with the Stolper-Samuelsson theorem. Both effects can be mitigated by the welfare state-but globalization also means that capital becomes more mobile across countries, constraining the opportunities for policy makers to compensate losers by expanding tax-financed transfers. When globalization increases, populists (especially the right-wing type) gain popularity by offering nationalism and protectionism as an alternative to economic globalization. Because protectionism also reduces the need for compensatory transfers, the welfare state can be cut, and populist parties can add lower taxes in their policy bundles.

The argument is theoretically coherent, but a number of problems are encountered with the standard interpretation of the compensation hypothesis (see Bergh (2019) for a fuller discussion). First, the premise that more open economies are more volatile (owing to, for example, globalization shocks) has been questioned. Down (2007) noted that 
economic theory instead suggests that openness should give rise to risk diversification that promotes rather than reduces stability. Down (2007) and Kim (2007) both present empirical evidence that more open economies are in fact not more volatile. However, those studies relied on data from before the 2008 financial crisis and more recent studies could very well find a different pattern.

Second, the evidence that economic openness constrains social spending is not very strong. It is true that capital has become more mobile, but capital taxes are not crucial for welfare state redistribution, which relies mainly on the taxation of labor income. Empirically, studies by Dreher et al. (2008), Meinhard and Potrafke (2012) and the survey by Potrafke (2015) all suggest that globalization may well be associated with lower tax revenues from capital - but not with lower total tax revenues or less government spending. On the other hand, Garrett (2001) showed that countries in which trade has expanded more quickly have had slower growth in public spending, suggesting at least some spending constraints induced by economic openness. The recent meta-survey by Heimberger (2020) also confirms the lack of strong unidirectional effects running from economic globalization to government spending, but does note that economic globalization may exert a small-tomoderate downward pressure on social expenditures.

The type of globalization is also worth some discussion. As noted by Rodriguez and Rodrik (2000), politicians do not control trade and investment flows directly, but rather the rules that govern those flows. It is clear from the debate and the micro-level studies cited in the introduction, that the main worry concerns flows (globalization de facto) rather than rules (globalization de jure). It is less clear whether the problems come from trade flows only or (also) from investment flows. We will rely on gross economic flows as our baseline, but also examine differences between trade and financial globalization, as well as the de jure/de facto distinction.

Apart from economic globalization, other factors may be in play that are related to globalization but remain outside the economic insecurity channel. Globalization could, for example, increase (the salience of) cultural threats and immigration (Margalit 2019; Lucassen and Lubbers 2011; Halikiopoulou and Vlandas 2020; Rydgren 2008; Oesch 2008), which according to the cultural-ethnic competition hypothesis will lead to more support for right-wing populist parties. Populism likewise has been associated with Euroskepticism and loss of national sovereignty (Biancotti et al. 2017; Rodrik 2018; Salgado and Stavrakakis 2019). Particularly interesting in our view is the observation made by Rodrik (2018) that right-wing populists in Europe portray the EU and the elites in Brussels as their enemy, rather than free trade.

\section{Data and empirical analysis}

The KOF globalization index is a panel normalized index ranging from 1 to 100, introduced by Dreher (2006) and recently updated by Gygli et al. (2019). As surveyed by Potrafke (2015), it has been used widely in research on the consequences of globalization. The index aggregates economic, social and political globalization using both de facto measures (such as trade and tourism) and de jure measures (such as tariff rates and airports). The index is useful for us because it allows us to zoom in on both trade globalization and financial globalization divided into de facto measures (consisting of actual trade 
Change in populism and globalization
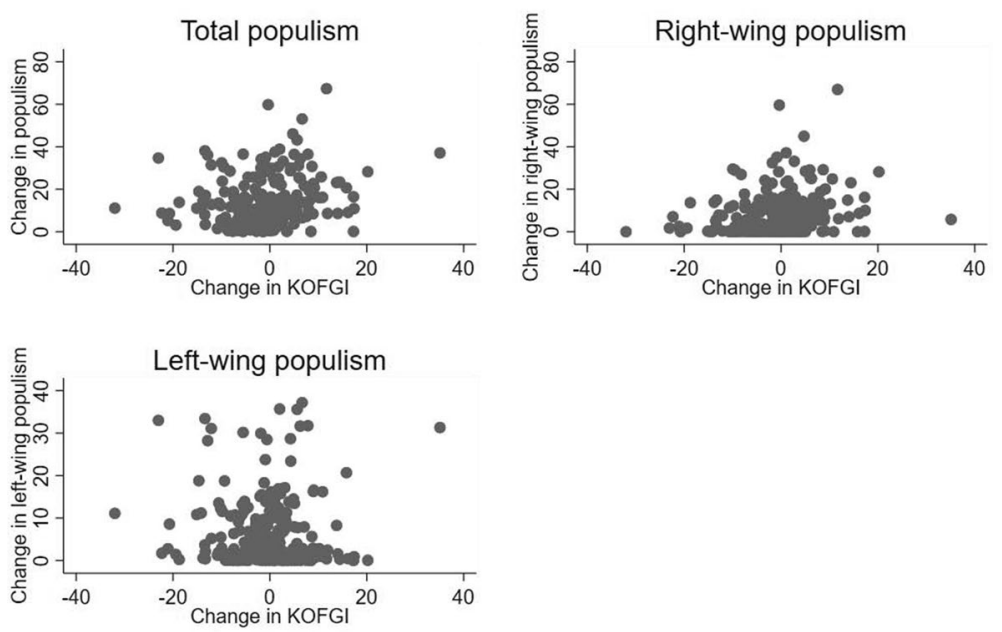

Sources: Heinö (2016) and Gygli et al. (2019)

Fig. 2 Populism and globalization over different time periods. Changes in vote shares for populist parties and KOF globalization score, 1980-1995, 1990-2005 and 2000-2015

flows and investment flows) on the one hand, and de jure measures (such as tariff rates and investment regulations) on the other. The index also allows us to zoom out and aggregate economic globalization with political and social globalization into one unified globalization measure. ${ }^{3}$ For further details regarding the index, see Gygli et al. (2019).

Starting with the broadest measures possible-aggregated globalization and total populism-Fig. 2 provides a visual inspection of the main variables by plotting changes in globalization against changes in populist vote shares over three different 15 -year periods. No visible association between the two is evident and no obvious outliers. It is worth noting that after having increased in the 1980s and 1990s, globalization declined from 2000 to 2015 in most countries in our sample.

We estimate the following regression

$$
Y_{i t}=\alpha+\gamma_{i t}+\beta X_{i t}+\delta_{t}+\phi_{i}+\epsilon_{i t},
$$

where $\gamma_{i t}$ is the globalization measure, $X_{i t}$ is a vector of control variables, $\delta_{t}$ are year fixed effects, $\phi_{i}$ are country fixed effects and $\epsilon_{i t}$ is an error term. The dependent variable $Y_{i t}$ represents the election results, measured in vote share percentages, for populist parties in country $i$ at year $t$, which is to be explained using a moving average of globalization for the preceding 5-year period (among the robustness tests we show that results are similar when using populism and globalization measured over the same time frame).

To control for demographic structure, we enter the population share aged 15-64 years (from the World Development Indicators). Education is the average years of education in the population aged 25-64, taken from the International Educational Attainment Database introduced by Cohen and Soto (2007) as an improvement over the Barro-Lee data. Our choice is,

\footnotetext{
3 The correlation between KOF de facto economic globalization and the standard measure of economic openness (trade/GDP) was examined by Graebner et al. (2018) and found to be 0.8 .
} 
however, guided mainly by availability: The Barro-Lee data end in 2010. An indicator for EU membership is also entered because many countries joined the European Union during the period studied and, as noted, joining the EU could entail a loss of sovereignty that might fuel populism. Table 1 contains summary statistics, Table 2 shows pairwise correlations.

\subsection{Results}

We start by regressing total populism on total globalization, entering as explanatory variables country and time fixed effects, controlling only for EU membership and demographic factors that plausibly are not endogenous to globalization in the short run: age structure and average education level. The results are shown in Table 3 and reveal no significant association between aggregate globalization and the vote shares of populist parties.

While aggregating different aspects of globalization into one uni-dimensional measure can sometimes be informative, it is clear from the opening Fukuyama quote, as well as many of the recent studies on globalization and political outcomes, that trade and investment flows are the types of globalization that are thought to breed populism. In Table 4 we therefore enter de facto economic globalization as our preferred globalization measure (reporting results for more aggregated and disaggregated measures among the robustness tests). We also consider results for right-wing and left-wing party vote shares separately. EU membership is negatively but insignificantly related to left-wing populist vote shares, but positively and significantly with the vote shares of right-wing populist parties. De facto economic globalization remains unrelated to both types of populist parties' vote shares.

Columns 3 and 6 in Table 4 contain our preferred estimates because they include controls for education and demography that are both unlikely to be caused by economic globalization in the short run, but do not control for potential mechanisms. The positive association between average education and right-wing populism deserves a comment. Given that education at the individual level typically is negatively associated with support for right-wing populist parties (see, e.g., Lubbers et al. 2002), our result potentially could be explained by less educated voters being more prone to populist voting in each country, while the average education of a country does not have the same effect. A similar observation regarding education is made by Caplan (2018), who noted that education often is found to raise individual incomes, but not as much at the country level. We suggest that the role of individual and country level education in explaining populism deserves further research.

So far we have not seen any evidence that economic globalization is positively related to the vote shares of (left-wing or right-wing) populist parties.

\subsection{Robustness checks and other types of globalization}

A panel-data model with both time and country fixed effects arguably is the standard approach in a setting like ours. It might be thought, however, that such a specification is too demanding for the hypothesis that globalization causes populism, for example because time fixed effects swallow too much of the variation in vote shares for populist parties, or because European countries are sufficiently similar to fit a random effects model. ${ }^{4}$ As

\footnotetext{
${ }^{4}$ In fact, a Hausman test barely rejects the random effects model for the right-wing populism regressions, but does not reject the random effects model for the left-wing populism regressions.
} 


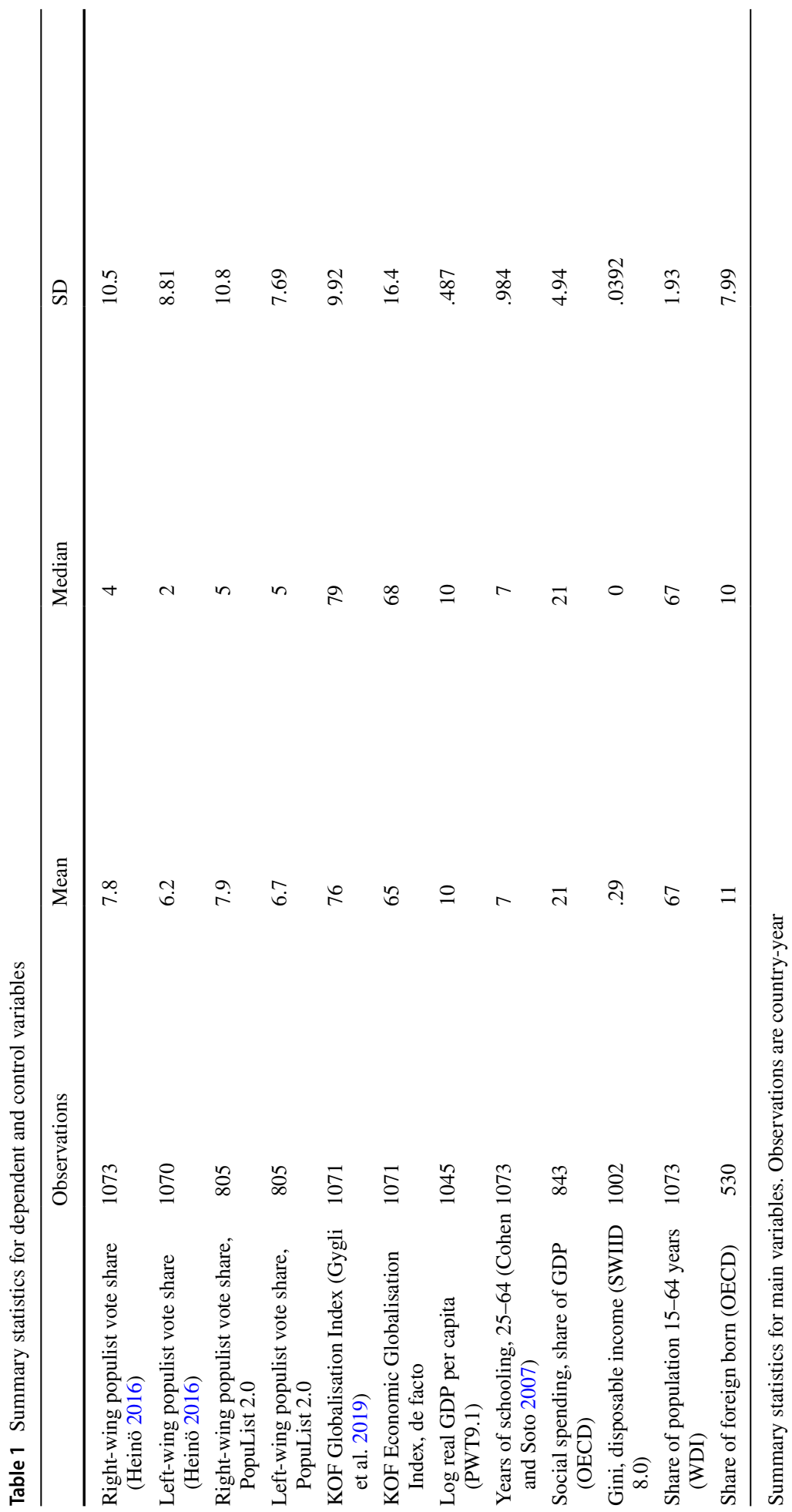




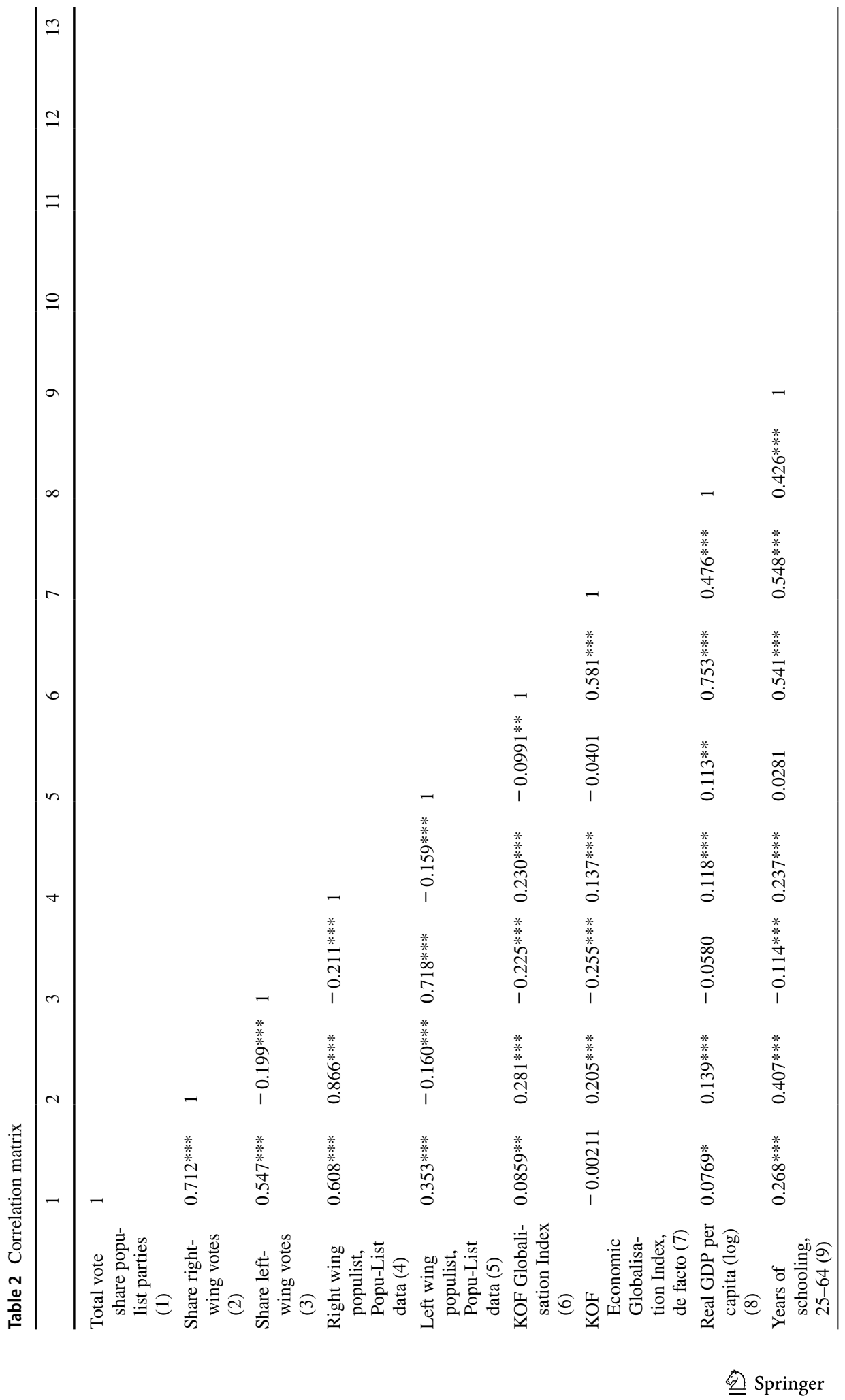




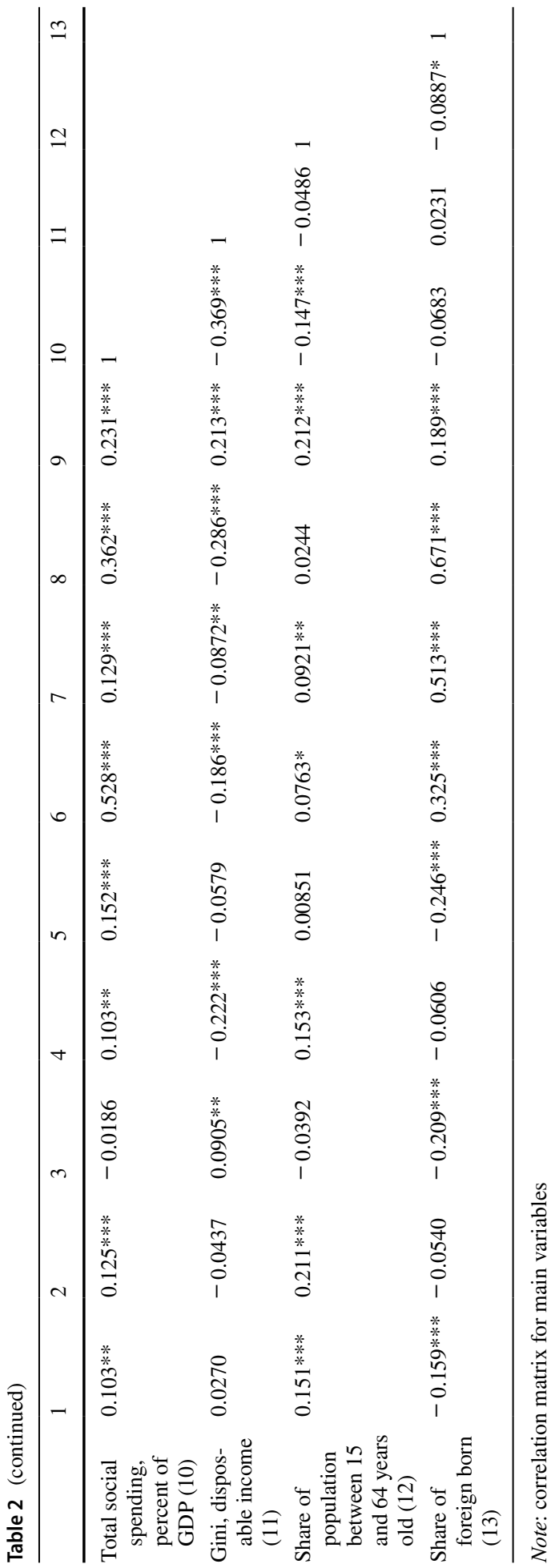


Table 3 Total populism

\begin{tabular}{llll}
\hline & $(1)$ & $(2)$ & $(3)$ \\
\hline 5-year moving average globalization & -0.11 & -0.29 & -0.20 \\
& $(0.25)$ & $(0.22)$ & $(0.21)$ \\
Dummy for EU membership & & 4.28 & 4.36 \\
& & $(3.34)$ & $(3.37)$ \\
Share of population between 15 and 64 years old & & & -0.60 \\
& & & $(0.56)$ \\
Years of schooling, 25-64 & & & $3.41^{* * *}$ \\
& 18.26 & $28.20^{*}$ & $(1.20)$ \\
Constant & $(16.05)$ & $(14.29)$ & 44.46 \\
& 1054 & 1054 & $(35.64)$ \\
Observations & 0.17 & 0.18 & 0.19 \\
R-squared & 33 & 33 & 33 \\
Number of countries & & & 0.19 \\
\end{tabular}

Dependent variable: total populism in percentage. Country and time fixed effects included. Robust standard errors in parentheses

$* * * p<0.01 ; * * p<0.05 ; * p<0.1$

Table 4 Right-wing and left-wing populism

\begin{tabular}{lllllll}
\hline & $(1)$ & $(2)$ & $(3)$ & $(4)$ & $(5)$ & $(6)$ \\
\hline $\begin{array}{l}\text { 5-year moving average } \\
\quad \text { economic globalization, }\end{array}$ & 0.10 & 0.03 & 0.05 & -0.14 & -0.12 & -0.14 \\
$\quad(0.15)$ & $(0.13)$ & $(0.14)$ & $(0.13)$ & $(0.14)$ & $(0.15)$ \\
$\quad$ de facto & & 4.23 & $5.59^{* *}$ & & -1.29 & -1.04 \\
$\begin{array}{l}\text { Dummy for EU } \\
\text { membership }\end{array}$ & & $(2.69)$ & $(2.53)$ & & $(1.94)$ & $(2.01)$ \\
$\quad \begin{array}{l}\text { Share of population } \\
\text { between 15 and }\end{array}$ & & & -0.37 & & & -0.42 \\
$\quad$ 64 years old & & & $(0.39)$ & & & $(0.40)$ \\
Years of schooling, & & & $2.24^{*}$ & & & 1.08 \\
$\quad$ 25-64 & -2.23 & -0.63 & $11.30)$ & & & $0.89)$ \\
Constant & $(7.15)$ & $(6.46)$ & $(26.47)$ & $(7.00)$ & $(7.31)$ & $(26.57)$ \\
& 1036 & 1036 & 1008 & 1033 & 1033 & 1007 \\
Observations & 0.26 & 0.28 & 0.32 & 0.08 & 0.08 & 0.09 \\
R-squared & 32 & 32 & 31 & 32 & 32 & 31 \\
Number of countries & & & & & & \\
\hline
\end{tabular}

Dependent variable: right- and left-wing populism in percentage. Country and time fixed effects included. Regressions 1-3 have right-wing populism as the dependent variable, 4-6 use left-wing populism as dependent variable. Robust standard errors in parentheses

$* * * p<0.01 ; * * p<0.05 ; * p<0.1$

summarized by the first four rows in Table 6, those choices have close to no effect on our main findings: Vote shares for both right-wing and left-wing populist parties are unrelated to de facto economic globalization, whereas EU membership is positively so. 
Table 5 Summary of robustness checks

\begin{tabular}{|c|c|c|c|c|}
\hline Robustness test & Glob-rw & Glob-lw & EU-rw & EU-lw \\
\hline \multicolumn{5}{|l|}{ Different models } \\
\hline \multirow[t]{2}{*}{ Baseline (Ec. glob., de facto) } & 0.00 & -0.14 & $4.78^{*}$ & -0.79 \\
\hline & $(0.13)$ & $(0.14)$ & $(2.54)$ & $(1.741)$ \\
\hline \multirow[t]{2}{*}{ No time FE } & 0.05 & -0.08 & $4.74^{*}$ & -0.35 \\
\hline & $(0.13)$ & $(0.10)$ & $(1.87)$ & $(1.87)$ \\
\hline \multirow[t]{2}{*}{ Random effects } & -0.01 & -0.14 & $4.31 *$ & -0.71 \\
\hline & $(0.11)$ & $(0.12)$ & $(2.40)$ & $(1.84)$ \\
\hline \multirow[t]{2}{*}{ Random effects, no time FE } & 0.04 & -0.08 & $4.39^{*}$ & -0.26 \\
\hline & $(0.11)$ & $(0.09)$ & $(2.60)$ & $(1.79)$ \\
\hline \multirow[t]{2}{*}{ Globalization not lagged } & -0.06 & -0.18 & $5.99 * *$ & -0.28 \\
\hline & $(0.12)$ & $(0.16)$ & $(2.77)$ & $(1.77)$ \\
\hline \multirow[t]{2}{*}{ Using 10 -year diff. in glob. } & 0.03 & -0.02 & 4.85 & -0.74 \\
\hline & $(0.10)$ & $(0.07)$ & $(3.21)$ & $(1.75)$ \\
\hline \multirow{2}{*}{$\begin{array}{l}\text { 10-year diff. in pop. and 10-year diff. in } \\
\text { glob. }\end{array}$} & $-0.28 *$ & -0.02 & -0.64 & $-5.40 * *$ \\
\hline & $(0.15)$ & $(0.11)$ & $(5.42)$ & $(1.79)$ \\
\hline \multirow[t]{2}{*}{ Difference GMM estimator } & -0.04 & -0.01 & 0.60 & 0.04 \\
\hline & $(0.07)$ & $(0.03)$ & $(0.93)$ & $(0.19)$ \\
\hline \multirow[t]{2}{*}{ ML estimator } & 0.03 & 0.02 & 0.10 & $-0.58 * *$ \\
\hline & $(0.02)$ & $(0.02)$ & $(0.37)$ & $(0.26)$ \\
\hline \multicolumn{5}{|l|}{ Different time periods } \\
\hline \multirow[t]{2}{*}{$1980-2000$} & -0.10 & -0.21 & -0.04 & 0.14 \\
\hline & $(0.15)$ & $(0.18)$ & $(2.64)$ & $(2.39($ \\
\hline \multirow[t]{2}{*}{ 2000-2017 } & 0.07 & -0.07 & 1.66 & -1.66 \\
\hline & $(0.21)$ & $(0.20)$ & $(2.91)$ & $(1.41)$ \\
\hline \multicolumn{5}{|l|}{ Different populism indicator } \\
\hline \multirow[t]{2}{*}{ The PopuList 2.0} & 0.14 & 0.04 & 4.15 & $-2.00 * *$ \\
\hline & $(0.12)$ & $(0.03)$ & $(2.72)$ & $(0.82)$ \\
\hline \multicolumn{5}{|l|}{ Different types of economic globalization } \\
\hline \multirow[t]{2}{*}{ Trade glob., de facto } & 0.22 & $(0.04)$ & 4.09 & -1.56 \\
\hline & $(0.15)$ & $(0.10)$ & $(2.47)$ & $(1.85)$ \\
\hline \multirow[t]{2}{*}{ Trade glob., de jure } & 0.01 & -0.06 & $4.64 *$ & -0.84 \\
\hline & $(0.12)$ & $(0.05)$ & $(2.29)$ & $(2.03)$ \\
\hline \multirow[t]{2}{*}{ Financial glob., de facto } & $-0.12 *$ & -0.15 & $5.53 * *$ & -0.51 \\
\hline & $(0.06)$ & $(0.09)$ & $(2.69)$ & $(1.76)$ \\
\hline \multirow[t]{2}{*}{ Financial glob., de jure } & 0.04 & -0.13 & $4.42 *$ & -0.22 \\
\hline & $(0.10)$ & $(0.08)$ & $(2.49)$ & $(1.69)$ \\
\hline \multicolumn{5}{|l|}{ Other types of globalization } \\
\hline \multirow[t]{2}{*}{ Social glob., de facto } & -0.17 & 0.01 & $5.36^{*}$ & -1.47 \\
\hline & $(0.17)$ & $(0.15)$ & $(2.81)$ & $(2.01)$ \\
\hline \multirow[t]{2}{*}{ Social glob., de jure } & 0.04 & -0.03 & $4.65^{*}$ & -1.35 \\
\hline & $(0.26)$ & $(0.12)$ & $(2.30)$ & $(1.67)$ \\
\hline \multirow[t]{2}{*}{ Political glob., de facto } & -0.01 & 0.04 & 4.79 & -1.49 \\
\hline & $(0.11)$ & $(0.06)$ & $(2.86)$ & $(1.77)$ \\
\hline Political glob., de jure & -0.06 & -0.04 & 5.33 & -1.08 \\
\hline & $(0.08)$ & $(0.05)$ & $(3.16)$ & $(1.85)$ \\
\hline
\end{tabular}


Table 5 (continued)

\begin{abstract}
Standard errors in parentheses. Glob-rw: The coefficient of globalization on right-wing populist vote share. Glob-lw: The coefficient of globalization on left-wing populist vote share. EU-rw: The coefficient of EU membership on right-wing populist vote share. EU-lw: The coefficient of EU membership on left-wing populist vote share

$* * * p<0.01 ; * * p<0.05 ; * p<0.1$
\end{abstract}

Changing the lag structure of the model so that populism and globalization are measured during the same 5-year period, the EU effect on right-wing populist votes increases by roughly one percentage point while leaving other results unchanged. The idea that changes in globalization over a 10-year period (as opposed to levels of globalization) matter more than levels of globalization is not supported. To check if long-run changes matter, we next regress changes in populism over 10 years on changes in populism over the same time. Doing so generates a weakly significant negative association for right-wing populism, and further disaggregation (see the online appendix) reveals that it is driven by financial globalization de facto.

When adopting a difference-GMM estimator and a maximum likelihood estimator (to possibly minimize bias from endogeneity and autocorrelation), the coefficients on both types of populism remain remarkably similar to OLS estimates (though the EU effect disappears). Similarly, the choice of time horizon (1980-2000 or 2000-2017) seems not to matter. We also verify the robustness of our findings by adopting a different classification of populist parties: PopuList 2.0. The positive effect of EU membership on right-wing populist vote shares remains but loses significance. On the other hand, a significant negative coefficient of EU membership on vote shares is found for left-wing populists.

Having verified the robustness of the main results to several methodological changes, we next examine both trade globalization and financial globalization de facto and de jure separately. Doing so reveals the largest coefficient so far (yet still insignificant) for trade globalization de facto on right-wing populist votes-but also a weakly significant negative association between de facto financial globalization and vote shares for right-wing populists. Changing the globalization measure to social and political globalization still reveals no significant associations. Robustness checks are summarized in Table 5.

\subsection{Mechanisms and moderators}

We have also examined how the empirical results change when some of the mechanisms that could play roles in determining the path from globalization to populism are taken into account. For example, globalization could affect GDP per capita (Dreher 2006; Irwin and Tervio 2002), the income distribution, or both (Potrafke 2015; Bergh and Nilsson 2010). We additionally examine the idea that social spending can undermine populism by entering an OECD standardized measure of social spending from its Social Expenditure Database (SOCX). As a proxy for the cultural-ethnic competition hypothesis, we control for countrylevel immigrant population shares, defined as persons born in another country (admitting that the proxy is imperfect because it does not account for the origins of immigrants). The results are shown in Table 6.

The main results are more or less unaffected; most controls are insignificant. It is worth noting, however, that Gini index inequality in disposable income is unrelated to populist party vote shares, and that the share of immigrants is significantly negatively related to the vote shares of right-wing populist parties. 


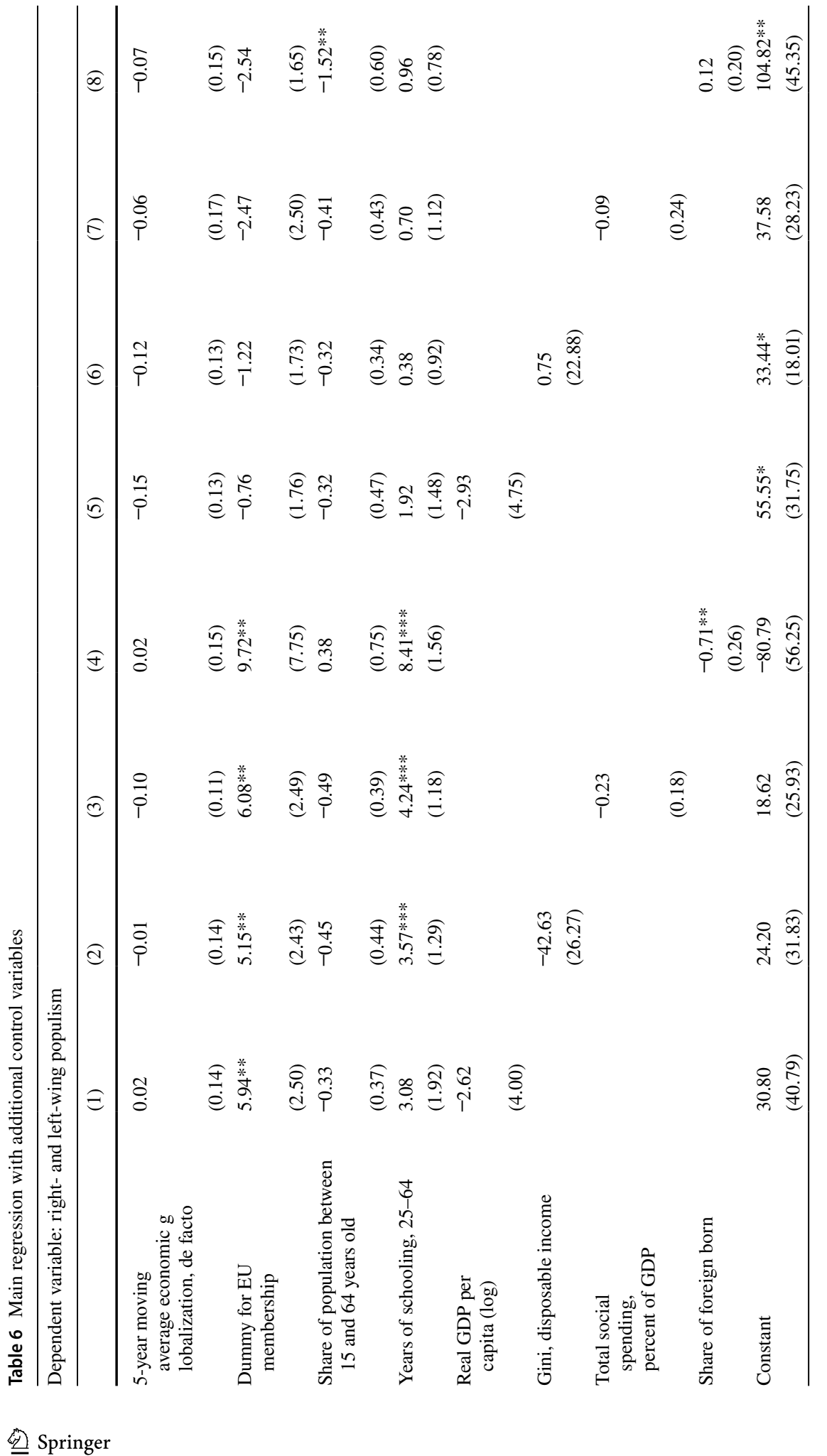




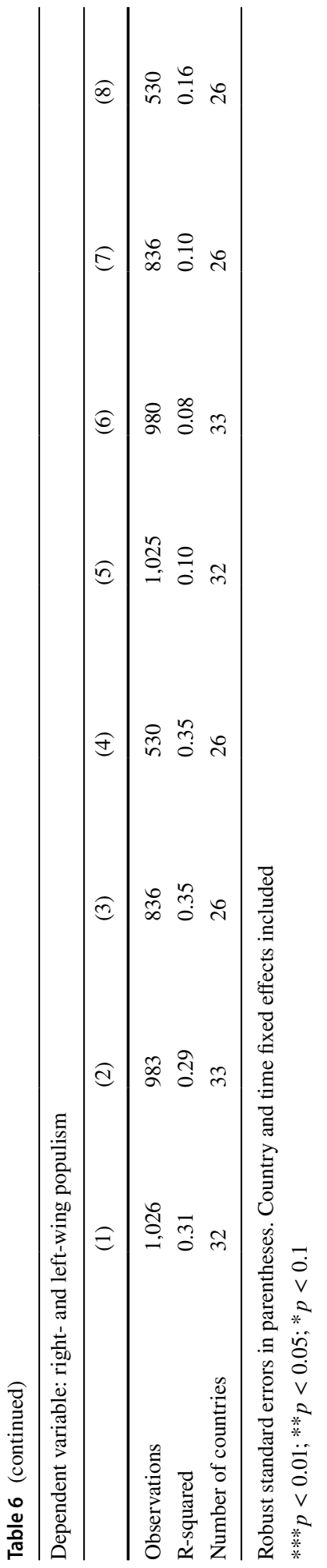


We finally the test idea that the effect that globalization has on populism is moderated or cushioned by social spending. Following Bergh et al. (2020), who showed that social spending does not moderate the effect of economic globalization on inequality, we do so by entering the interaction between globalization and social spending (full results in the online appendix). The interaction effect is close to 0 and far from significant, suggesting that globalization is unrelated to populism regardless of the level of social spending.

Summarizing the results regarding mechanisms and moderators, we have failed to find support for the idea that de facto economic globalization is associated with larger vote shares for populist parties, either by increasing inequality, by lowering social spending, by affecting GDP per capita, or through other channels holding inequality, social spending and GDP per capita constant. We also find no support for the idea that economic globalization breeds populism only when social spending is low.

\section{Conclusions}

Our results do not suggest that countries that are more globalized economically have larger populist parties. The association between de facto economic globalization and the vote share of right-wing and left-wing populist parties is insignificant in our baseline; so are almost all different types of globalization (goods and financial) in our robustness tests. The only exception is a weakly significant negative (!) association between financial globalization de facto and vote shares for right-wing populist parties. It should, however, be noted that the absence of a significant correlation across 33 countries does not rule out local, and even causal, effects on the micro level as suggested by several previous studies. Further research into that topic is warranted.

In contrast, EU membership is associated with around a 4-6-percentage-point (roughly half a standard deviation) larger vote share for right-wing populist parties; the effect is relatively robust. One could argue that EU membership is a form of globalization, in the sense that individual countries surrender some sovereignty to a transnational entity. Indeed, the slogan for the Brexit campaign was "Take back control". Abreu and Öner (2020), for instance, find that cultural issues were important for voters. However, EU membership affects European countries in ways that are different from those related to wider economic globalization. It is tempting to contrast that finding with the stated goals and values of the European Union, including tolerance, inclusion, justice and non-discrimination, as well as social and territorial cohesion and solidarity. The fact that EU membership is associated with larger right-wing populist parties thus arguably represents a political failure. ${ }^{5}$ Our results suggest that the discussion of populism and globalization should make a clear separation between globalization in the form of EU membership and sovereignty, and globalization in the form of trade, with only the former being correlated with an increase in populism.

Acknowledgements The authors are grateful to Joakim Skoog and seminar participants at the Spanish and Danish Public Choice Workshops for helpful comments, as well as Philipp Mendoza for generously sharing data. Financial support from the Jan Wallander and Tom Hedelius Foundation is gratefully acknowledged (Grant P2019-0180 for Bergh, P2018-0162 for Kärnä).

5 The goals and values of the EU are described on the official webpage. 
Funding Open access funding provided by Örebro University.

Open Access This article is licensed under a Creative Commons Attribution 4.0 International License, which permits use, sharing, adaptation, distribution and reproduction in any medium or format, as long as you give appropriate credit to the original author(s) and the source, provide a link to the Creative Commons licence, and indicate if changes were made. The images or other third party material in this article are included in the article's Creative Commons licence, unless indicated otherwise in a credit line to the material. If material is not included in the article's Creative Commons licence and your intended use is not permitted by statutory regulation or exceeds the permitted use, you will need to obtain permission directly from the copyright holder. To view a copy of this licence, visit http://creativecommons.org/licenses/by/4.0/.

\section{Appendix}

In Figures 3, 4 and 5, we show both the trend in globalization and populism and the changes in the two. While increasing globalization and increasing populism is obvious, no correlation between changes in globalization and changes in populism is evident.

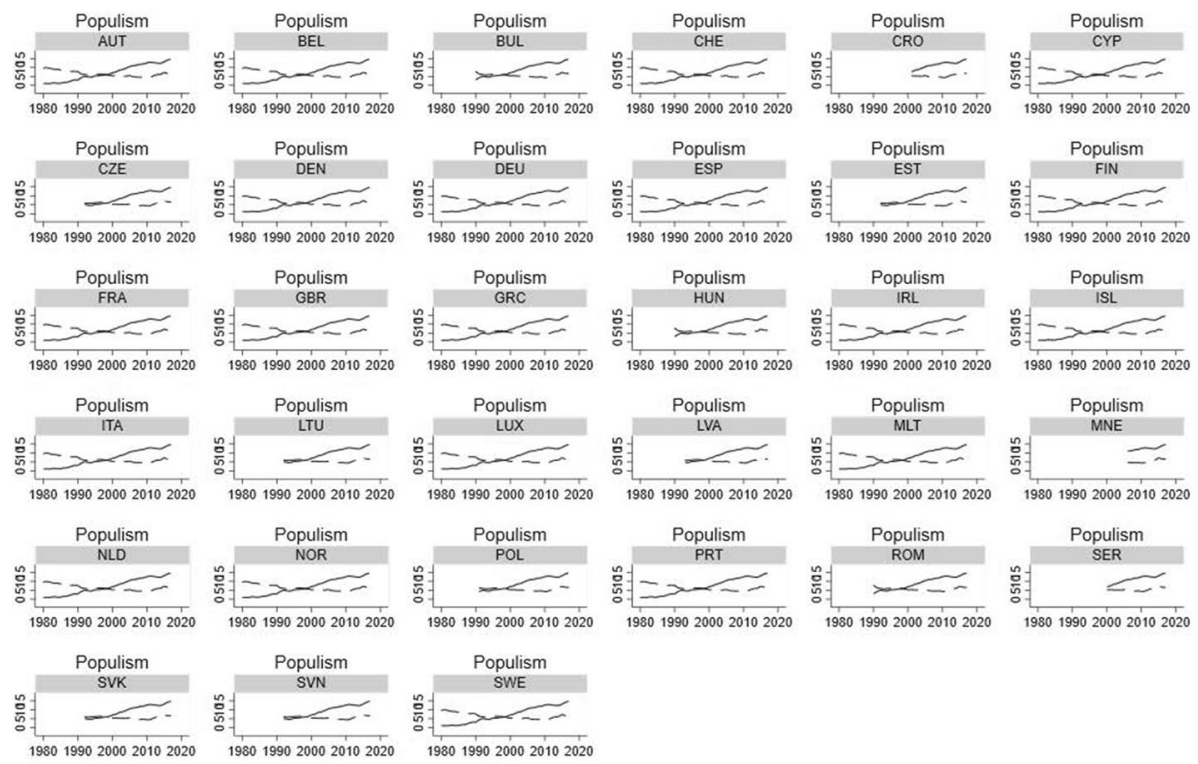

\begin{tabular}{|llll}
\hline & Right-wing populism $\quad-----$ & Left-wing populism \\
\hline
\end{tabular}

Fig. 3 Right-wing and left-wing populism by country 


\section{Populism and globalization}
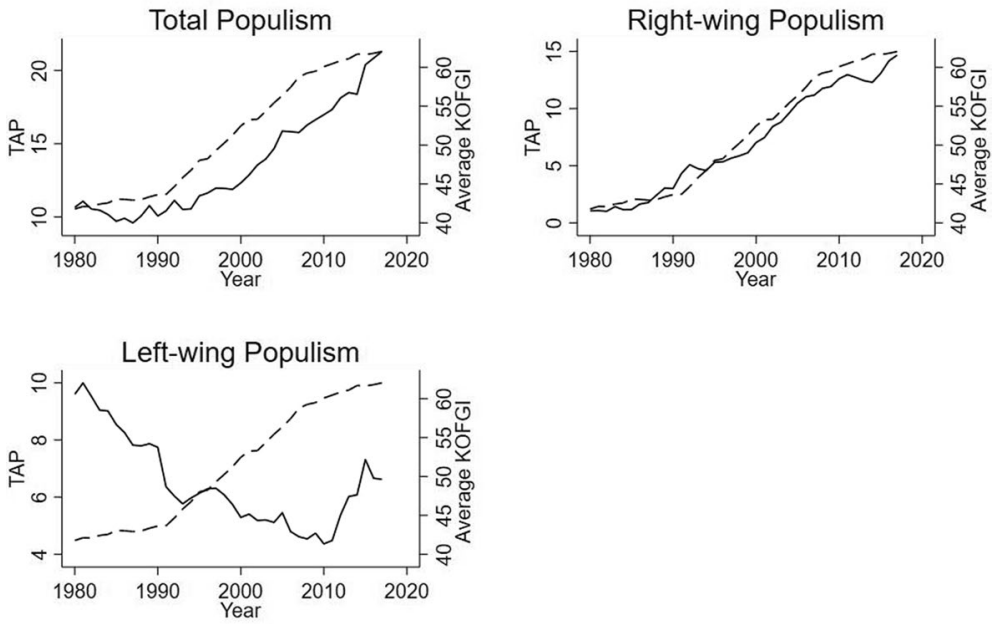

Sources: Heinö (2016) and Gygli et al. (2019)

Fig. 4 Average populism and globalization for all countries

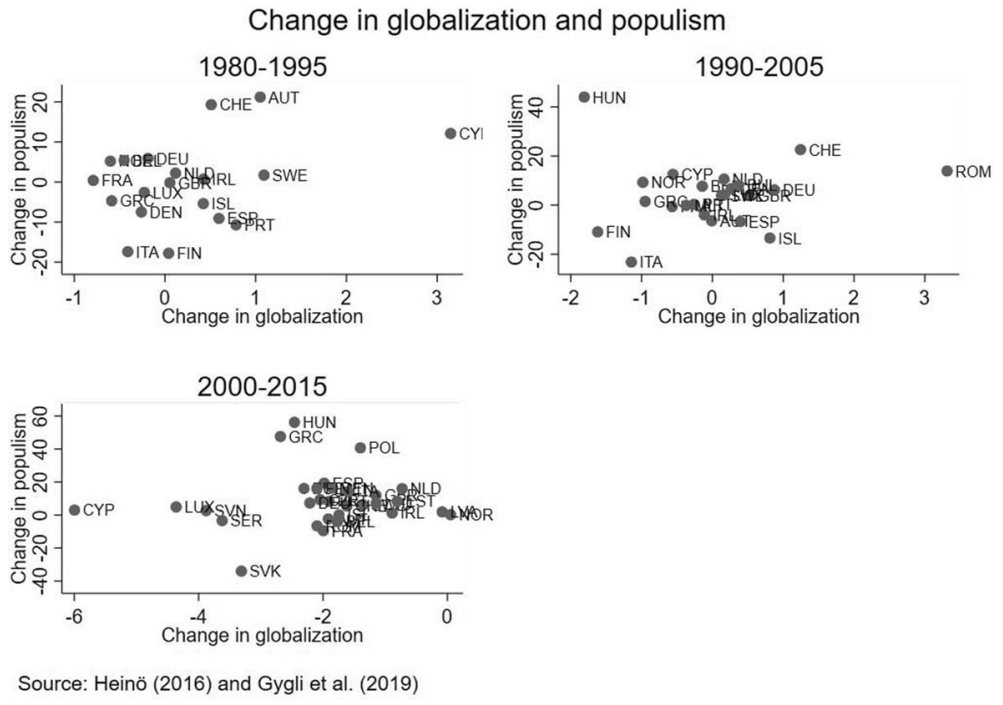

Fig. 5 Changes in populism and globalization 


\section{References}

Abreu, M., \& Öner, Ö. (2020). Disentangling the Brexit vote: The role of economic, social and cultural contexts in explaining the UK's EU referendum vote. Environment and Planning A: Economy and Space,. https://doi.org/10.1177/0308518X20910752.

Auspurg, K., \& Hinz, T. (2011). What fuels publication bias? Jahrbücher für Nationalökonomie und Statistik, 231(5-6), 636-660.

Autor, D., Dorn, D., Hanson, G., \& Majlesi, K. (2020). Importing political polarization? The electoral consequences of rising trade exposure. American Economic Review, 110(10), 3139-83.

Bergh, A. (2020). The compensation hypothesis revisited and reversed. Forthcoming in Scandinavian Political Studies.

Bergh, A., Mirkina, I., \& Nilsson, T. (2020). Can social spending cushion the inequality effect of globalization? Economics and Politics, 32(1), 104-142.

Bergh, A., \& Nilsson, T. (2010). Do liberalization and globalization increase income inequality? European Journal of Political Economy, 26(4), 488-505.

Biancotti, C., Borin, A., \& Mancini, M. (2017). Euroscepticism: Another brick in the wall. Memo, Bank of Italy.

Canovan, M. (1981). Populism. San Diego: Harcourt Brace Jovanovich.

Caplan, B. (2018). The case against education: Why the education system is a waste of time and money. Princeton: Princeton University Press.

Cohen, D., \& Soto, M. (2007). Growth and human capital: Good data, good results. Journal of Economic Growth, 12(1), 51-76.

Colantone, I., \& Stanig, P. (2018a). Global competition and brexit. American Political Science Review, 112(2), 201-218.

Colantone, I., \& Stanig, P., (2018b). The trade origins of economic nationalism: Import competition and voting behavior in Western Europe. American Journal of Political Science, 62(4), 936-953.

Dippel, C., Gold, R., \& Heblich, S. (2015). Globalization and its (dis-) content: Trade shocks and voting behavior. Technical report 21812, National Bureau of Economic Research.

Down, I. (2007). Trade openness, country size and economic volatility: The compensation hypothesis revisited. Business and Politics, 9(2), 1-20.

Dreher, A. (2006). Does globalization affect growth? Evidence from a new index of globalization. Applied Economics, 38(10), 1091-1110.

Dreher, A., Sturm, J.-E., \& Ursprung, H. W. (2008). The impact of globalization on the composition of government expenditures: Evidence from panel data. Public Choice, 134(3), 263-292.

Fukuyama, F. (2019). Fukuyama replies. Foreign Affairs, 98(2), 168-170.

Garrett, G. (2001). Globalization and government spending around the world. Studies in Comparative International Development, 35(4), 3-29.

Graebner, C., Heimberger, P., Kapeller, J. et al. (2018). Measuring economic openness: A review of existing measures and empirical practices. Technical report, Johannes Kepler University, Institute for Comprehensive Analysis of the Economy.

Gygli, S., Haelg, F., Potrafke, N., \& Sturm, J. E. (2019). The KOF Globalisation Index-revisited. Review of International Organizations.

Halikiopoulou, D., \& Vlandas, T. (2020). When economic and cultural interests align: The anti-immigration voter coalitions driving far right party success in Europe. European Political Science Review, 12, 1-22.

Heimberger, P. (2020). Does economic globalization affect government spending? A meta-analysis. Public Choice,. https://doi.org/10.1007/s11127-020-00784-8.

Heinö, A. J. (2016). Timbro authoritarian populism index. Timbro. https://timbro.se/allmant/timbr o-authoritarian-populism-index.

Huber, R. A., \& Schimpf, C. H. (2017). On the distinct effects of left-wing and right-wing populism on democratic quality. Politics and Governance, 5(4), 146-165.

Irwin, D. A., \& Tervio, M. (2002). Does trade raise income? Evidence from the twentieth century. Journal of International Economics, 58(1), 1-18.

Katzenstein, P. (1985). Small states in world markets: Industrial policy in Europe. Ithaca, NY: Cornell University Press.

Kim, Y. S. (2007). Openness, external risk, and volatility: Implications for the compensation hypothesis. International Organization, 61(1), 181-216.

Krugman, P. (2016). Trade and jobs: A note. The New York Times.

Lubbers, M., Gijsberts, M., \& Scheepers, P. (2002). Extreme right-wing voting in Western Europe. European Journal of Political Research, 41(3), 345-378. 
Lucassen, G., \& Lubbers, M. (2011). Who fears what? Explaining far-right-wing preference in Europe by distinguishing perceived cultural and economic ethnic threats. Comparative Political Studies, 45(5), 547-574.

Margalit, Y. (2019). Economic insecurity and the causes of populism, reconsidered. Journal of Economic Perspectives, 33(4), 152-170.

Meinhard, S., \& Potrafke, N. (2012). The globalization-welfare state nexus reconsidered. Review of International Economics, 20(2), 271-287.

Mudde, C. (2004). The populist Zeitgeist. Government and Opposition, 39(4), 541-563.

Mudde, C., \& Kaltwasser, C. R. (2017). Populism: A very short introduction. Oxford: Oxford University Press.

Müller, J.-W. (2016). What is populism?. Philadelphia: University of Pennsylvania Press.

Norris, P., \& Inglehart, R. (2019). Cultural backlash: Trump, Brexit, and authoritarian populism. Cambridge: Cambridge University Press.

Oesch, D. (2008). Explaining workers' support for right-wing populist parties in Western Europe: Evidence from Austria, Belgium, France, Norway, and Switzerland. International Political Science Review, 29(3), 349-373.

Otjes, S., \& Louwerse, T. (2015). Populists in parliament: Comparing left-wing and right-wing populism in the Netherlands. Political Studies, 63(1), 60-79.

Potrafke, N. (2015). The evidence on globalisation. The World Economy, 38(3), 509-552.

Rodriguez, F., \& Rodrik, D. (2000). Trade policy and economic growth: A skeptic's guide to the crossnational evidence. NBER Macroeconomics Annual, 261-325.

Rodrik, D. (1998). Why do more open economies have bigger governments? The Journal of Political Economy, 106(5), 997-1032.

Rodrik, D. (2018). Populism and the economics of globalization. Journal of International Business Policy, $1(1-2), 12-33$.

Rosenthal, R. (1979). The file drawer problem and tolerance for null results. Psychological Bulletin, 86(3), 638-641.

Ruggie, J. G. (1982). International regimes, transactions, and change: Embedded liberalism in the postwar economic order. International Organization, 36(02), 379.

Rydgren, J. (2008). Immigration sceptics, xenophobes or racists? Radical right-wing voting in six West European countries. European Journal of Political Research, 47(6), 737-765.

Salgado, S., \& Stavrakakis, Y. (2019). Introduction: Populist discourses and political communication in Southern Europe. European Political Science, 18(1), 1-10.

Stanley, T. D. (2005). Beyond publication bias. Journal of Economic Surveys, 19(3), 309-345.

Swank, D., \& Betz, H.-G. (2003). Globalization, the welfare state and right-wing populism in Western Europe. Socio-Economic Review, 1(2), 215-245.

Taggart, P. (2000). Populism: Concepts in the social sciences. Buckingham: Open University Press.

Taggart, P. (2004). Populism and representative politics in contemporary Europe. Journal of Political Ideologies, 9(3), 269-288.

Publisher's Note Springer Nature remains neutral with regard to jurisdictional claims in published maps and institutional affiliations. 